LWSA

PAPER - OPEN ACCESS

\title{
The Reflection of Kebhinekaan (Unity In Diversity) in Indomie Advertisement: A Multiomdal Study
}

\author{
Author : Fikry Prastya Syahputra \\ DOI $\quad: 10.32734 /$ lwsa.v1i2.204 \\ Electronic ISSN : :2654-7066 \\ Print ISSN :2654-7058
}

Volume 1 Issue 2 - 2018 TALENTA Conference Series: Local Wisdom, Social and Arts

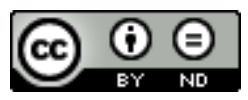

This work is licensed under a Creative Commons Attribution-NoDerivatives 4.0 International License.

Published under licence by TALENTA Publisher, Universitas Sumatera Utara
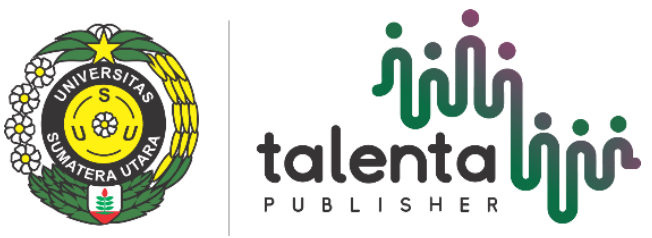


\title{
The Reflection of Kebhinekaan (Unity In Diversity) in Indomie Advertisement: A Multiomdal Study
}

\author{
Fikry Prastya Syahputra ${ }^{a^{*}}$, Tengku Silvana Sinar ${ }^{\mathrm{b}}$ \\ ${ }^{a}$ Student at Post-Graduate School of Linguistic, University of Sumatera Utara, Medan, Indonesia, 20155 \\ ${ }^{b}$ Lecturer/Supervisor in University of Sumatera Utara, Medan, Indonesia \\ fikry.gokil@gmail.com
}

\begin{abstract}
This paper was made to analyze Indomie advertisement in Indonesia. The analysis in this paper used qualitative approach focused on multimodal text system which is include linguistic, audio, gestural, and position aspects. The resource of data in this research is Indomie's advertisement which aired in Indonesia TVearly 2010. The data were verbal and visual elements in the advertisement. The result of the analysis revealed that all five of this multimodal system was integrated in the advertisement. Those five systems functioned as message deliverer, theme and concept maker, also information distributor about the product. Based on the result of the research, the Indomie advertisement delivers a message of togetherness which intertwined on the advertisement's linguistic aspect. The visual aspect showed diversity which finally took up the theme of kebhinekaan which become a unique appeal from the advertisement. The conclusion is the advertisement has all multimodal system and also a product with an attractive cultural touch.
\end{abstract}

\section{Introduction}

As one of the promotion media, advertisement actually does not have to be attractive, nowadays, a lot of advertisement which took the concept of culture or moral message inside it. Advertisement is a message which offers a product to the society through a media [1]. The media can be in a printed media such as newspaper or magazine, or in electric media such as advertisements in television. Electronic advertisement in television combines the elements of sounds, images and language in delivering its message. That is why advertisement is included in multimodal text. When there are two or more modes inside a text (verbal and non-verbal) that text is a multimodal text [2]. a message which in a multimodal text is quite complex because it has more than one mode of message deliverer. That is why a multimodal analysis is needed to see what message it has.

Television advertisements which are actually used to help promoting a product selling, now are showed in various ways to attract the customer. From using a famous model, am attractive slogan, nice background music, until bringing up a unique concept. Especially for products which is in a competitive market state. Advertisement also influences the customer decision to choose a product [3]. Indomie is one of it, this instant noodle product has a lot of competitors in the market. One of the factor that helped the selling is advertisement. The interesting part from one of the Indomie advertisement is when we connect it with the current social state of this country. A lot of issues are threatening the solidarity and sovereignty of this country spreading out there. But, actually PT. Salim Group already took up this issue before. 
The research of this advertisement in linguistics will lead to the multimodal point of view like Rosa [4]. Rosa [4] analyzed the elements of multimodal in television advertisement. The theory which used by Rosa [4] to analyze the multimodal text is Cheong (2004), Chandler (2007), Anstey and Bull (2010), and also Schmidt (2012). This research will analyze the multimodal elements in Indonesia version of Indomie advertisement. The Indomie advertisement was chosen because of the availability of the official data and also the popularity in domestically and also internationally. The analysis was done to find out the multimodal elements from the advertisement which are; linguistic, visual, audio, gestural, and position [5].

This research was done to reveal the point of view of Kebhinekaan which poured in the Indomie advertisement. This concept is rarely used for food product advertisement. By seeing how Indomie inserted Kebhinekaan in its advertisement, it is also hoped that can be role model for the society to recover the firm solidarity and being immune to the harmful issues.

The object of this research is advertisement, just like how and advertisement text which belong to multimodal text, all interaction that combine two modes which could give a combination meaning on a language which are verbal and non-verbal is called multimodal [2]. Advertisement which consists of verbal text and non-verbal text has logical relations which deliver a meaning. Those relations can be known from the relationship between the meta-function component in a verbal text and non-verbal text. Text are limited to its functional meaning in a social context which stated that text can be in a form of a script, paragraph, complex clause, clause, phrase, group, or sound. The text which is a language unit has a meaning in a social context is occurred because the present of communication interaction. All those communication interactions are called multimodal.

Furthermore, this research used theory which stated by Anstey and Bull [5] in analyzing multimodal text. Anstey and Bull [5] stated that a text can be defined as multimodal when two or more semiotic systems are combined. They took an example of an audio-visual food advertisement, which then analyzed using multimodal based on the semiotic system. Below are the five semiotic systems:

- Linguistic: Includes aspects such as diction, generic structure, and spoken and written language grammar.

- Visual: Includes aspects such as color, vector and point of view to the static and moving object. Such as face expression which can be done with angry, happy, mad, surprised, scared, and hate. Then sign, the meaning of a sign can be different in every culture which often rise an issue of perception. Sign happens as reflection without any plan. And then eye contact, the important thing in non-verbal such as attention or attraction to the interlocutors.

- Audio: Includes aspects such as volume, high or low the music note and rhythm and sound effect. In spoken communication, voice become the main object such as high pitch voice, soft voice, or moaning voice.

- Gestural: Includes aspects such as: movement, speed, and silence in facial expression and body language. Such as sitting manners, looking, moving, and holding head which can gives impressions of giving an attention to something or do not care and confused. And then touch such as handshake, taping a shoulder, playing hair, or hugging which give an expression of familiarity.

- Spatial: Includes aspects such as far or close the place of an object, direction, layout position, and distance adjustment based on position.

\section{Research method}

This research is a case study where the result might differ if a similar research was done to a quite similar object. Even though this is a case study, the research problem was explained descriptively with qualitative method approach. Sugiyono [6] stated that descriptive method is a method which used to describe or analyze a research's result but it is not to be used to make a further conclusion. While Moleong [7] wrote that the resource of qualitative research is a display in a form of spoken or written words which observed by researcher, and objects were observed as detail as possible so the meaning inside the object can be determined. 


\subsection{Data and data sources}

Arikunto [8] stated that "Resource of data in a research is subject where the data can be received". The resource of data in this research is a video which downloaded from Youtube.com. The video is an advertisement which was aired in Indonesia television. That video is a television advertisement which marketing an Indonesian product which is an instant noodle product, Indomie. The video duration is 1 minute. The language in the video was Bahasa Indonesia and it was aired in Indonesia television. The data which can be received from that resource are images (visual) also word, phrase, clause, and sentence (verbal) in the image/video. The next part is a dialogue in a form of voice (audio) and the audio's transcript in a form of written verbal. Just like Munday [9] stated, in an advertisement text, every aspect such as image or voice needs to be perceived. "In order for an advertisement to be successful transculturally, the verbal message it contains, the accompanying visuals and the product itself, need to be perceived as though they originated in the target culture." [9]. The way to receive the data is corresponding with the multimodal text analysis which observe image as materialization from model, text, background and color choice, and voice which came from dialogue between the model and background song.

\subsection{Data collecting method}

The method which was used in data collecting is observation technique and documentation technique. According to Sugiyono [6] documentation technique is a complementary for observation and interview method in a qualitative research. Both of the videos were observed, and then the data in forms of word, phrase, clause and sentence were taken. The kind of observation which was used is a non- structural observation. Non-structural observation is an observation which was done without using an observation guide. In this observation, the researcher should be able to develop the observation skill in observing an object [10]. This kind of observation was chosen because the object could not give a response to the researcher. So the researcher needs to develop the observation skill.

\section{Result and discussion}

The linguistic element which was found from the Indonesian version of the Indomie advertisement was on the words which corresponding to the background song (audio/spoken) in the advertisement. That linguistic element was narrated by a narrator which was not shown in the advertisement. There is also some linguistic element which came up from the image (visual/written). Those words came up directly in the advertisement and not spoken. Below is the linguistic element which was found from the Indonesian version of Indomie advertisement;

Table. 4.1.Linguistic Element in Indonesian Indomie Advertisement.

\begin{tabular}{ll}
\hline $\begin{array}{l}\text { Linguistic Element which narrated/sung corresponding to the } \\
\text { background song (audio/spoken) }\end{array}$ & $\begin{array}{l}\text { Linguistic Element which came up in visual form(written } \\
\text { language) }\end{array}$ \\
\hline $\begin{array}{l}\text { 1. dari sabang sampai merauke } \\
\text { 2. ada semangat awali pagi }\end{array}$ & "Ada semangat dan kehangatan yang menemani Indonesia" \\
3. yang selalu hadirkan ceria \\
4. kehangatan sepanjang hari \\
5. Indomie, Indomie seleraku \\
6. Indomie dari dan bagi ... Indonesia
\end{tabular}

To determine the meaning which contained in the words which came up in linguistic element, language metafunction analysis by Halliday [11] was used.

The function which was analyzed is the experiential which contained in the ideational meaning. Below is the experiential meaning determination in linguistic element from the Indonesian version of Indomie advertisement. The function of this determination is to find out the meaning which contained in the advertisement verbal. Because in the linguistic element in Indonesian version was made like a song lyric, in this analysis those words groups are adjusted with the note and interlude, and then named as line 


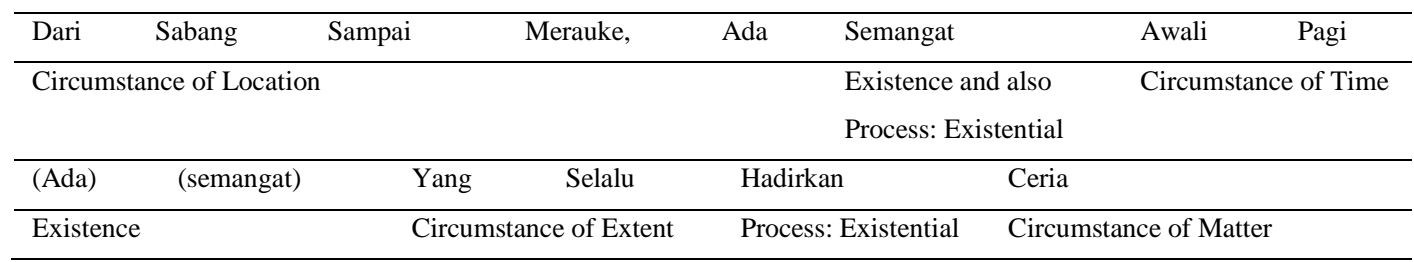

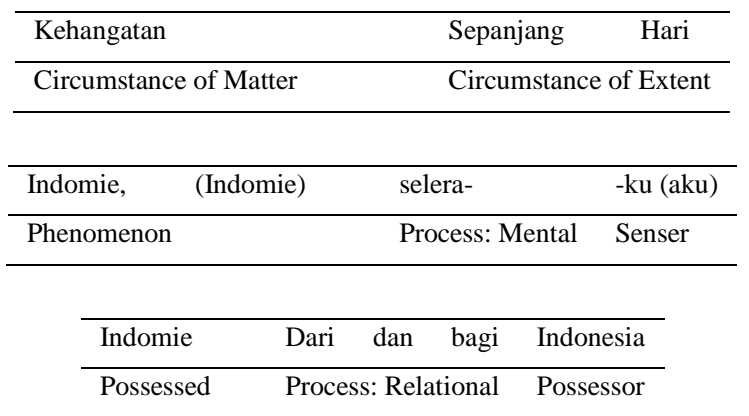

The linguistic element in Indomie advertisement was matched with the visual description in the advertisement. Every word which came out symbolize meanings that the producer wants to deliver to the consumer. The words 'SabangsampaiMerauke' is a circumstance of location that give a meaning to the consumer that Indonesia contains as a whole from the very west to the very east of the country.

The first and second lines are existential function. This function gave a meaning of matter or existential of something [11]. If related to the linguistic elements which a song, the first line is the verse. Just like a verse that functions as an introduction or a beginning of a song. In this first line if we did not know the thing that being advertised, then we would not know that Indomie is the one that gave spirit to start the day. That Indomie always be there to give a spirit in the morning for the Indonesian people from Sabang to Merauke.

The third line also an existential process. This line is the continuation of the first and second line which gave the existential of the Indomie product. The existence is happiness. The word ceria on the third line is the circumstance of matter. The writer's thought, the word semangat at the beginning of the lyric is the symbol of Indomie itself. This writer's thought later will be supported by explanation in visual element of the advertisement.

Then, in the fourth and fifth line, the product is already been pointed out. The fourth line is the mental process. The word seleraku divided to selera and $a k u$. Aku is the senser, selera is the mental process and Indomie as the phenomenon. Aku isbeing the representative of Indonesian people. This can be seen from the beginning of the advertisement that this advertisement had no main model. This mental process indicates that 'aku' felt something towards 'Indomie'. Meanwhile, according to the KBBI, one of the meaning of the word selera is 'nafsu makan' (appetite) with an example 'selera aku melihat rendang itu' and has a similar meaning with like/favorite. The writer concluded that in this line the meaning that given is the feeling (mental process) of Indonesian people to the Indomie. Of course, the favorable feeling toward Indomie, the feeling that assumed Indomie is the favorite food of Indonesian people or Indomie is a food that can give an appetite.

The fifth or the last line in the linguistic element of the lyrical Indonesian version Indomie advertisement is the line with relational process. Relational process is a process which has visible relation (world of abstract relation, Halliday, 2004). That relation can be a symbol, identity possession, or attribute possession [11]. Indomie has a role as the possessor, meanwhile the word combination dari dan bagi has a meaning of relational process and Indomie is the thing which possessed by Indonesia. Indomie from Indonesia or Indomie originated from Indonesia. Indomie for Indonesia or Indomie gave spirit, happiness, and warmth for Indonesian people. 
To the written linguistic element,

\begin{tabular}{|c|c|c|c|c|}
\hline Ada & semangat & Kehangatan & menemani & Indonesia \\
\hline Actor & & & Process: Material & Recipient \\
\hline
\end{tabular}

This clause has material process. Material process is a process of doing, in other word a process that include physical activity [11]. Spirit and warmth as the actor that (as if) doing an activity of 'accompanying' Indonesian people from Sabang to Merauke, from morning until evening.

In linguistic element, Indonesian version advertisement text showed in written and spoken. Linguistic element which came out then analyzed used language meta-function theory from Halliday (2004). This is in accordance to a research from Rosa [4] which also added language meta-function analysis from Halliday [11] on linguistic element in one of the shampoo advertisement in Indonesia.

In linguistic element, there are more messages and meanings about togetherness in kebhinekaan (unity in diversity) can be seen. This kebhinekaan element used by Indomie producer as the main message in every product. That can be seen from the Indomie official website, the slogan berbeda-beda satu selera which is an adaptation from Bhineka Tunggal Ika (stay as one in diversity) can be found in the website.

From this advertisement observation, some of the values which formed the visual element of the multimodal text can be found. Those values are;

\begin{tabular}{ll}
\hline$\underline{\text { Value }}$ & $\underline{\text { Visualization }}$ \\
\hline Background of Location & 1. Dermaga 2. Boat 3. Kitchen 4. Floating House \\
& 5. Plantation 6. Meadow 7. Beach8. Mountains \\
& 9. Coffee Shop 10. Night Market 11. Office \\
Background of Time & 1. Dawn 2. Morning 3. Afternoon 4. Dusk 5. Evening \\
Object & A man and a boy. A woman anda girl. Cultural artifact; Batik decoration. Unprocessed and processed \\
& product. \\
\hline
\end{tabular}

In the Indonesian version of the advertisement, contained some gesture that indicates message and theme. There are also activities that built a message. Below are the gestures and activities that contained in the Indonesian version of the advertisement:

\begin{tabular}{lll}
\hline Gestures and Activities & & Messages andPurposes \\
\hline Eating together (6) & $=$ & Togetherness, product promotion \\
Cooking & $=$ Product promotion \\
Stroking & $=$ Warmth, togetherness \\
Helping each other & $=$ Togetherness \\
Playing football & $=$ Togetherness, happiness \\
Swimming & $=$ Togetherness, happiness \\
\hline
\end{tabular}

There are six gestures that showed the scene of eating together, suitable with the product which is food. The eating together scene is the most suitable to deliver a message and also promoting this product.The Gestural element on the Indonesian version advertisement generally divided into two; which arerelated to the message and related to the product.The findings that related with the message are the gestures that showed togetherness such as; playing together which showed the children playing football and also a group children swimming together.The activities of 
playing football and swimming which are described was done by a group of boys showed togetherness and happiness.

In the Indonesian version of the advertisement, the product can be seen several times in packaged and also readyto-eat form. The placement was not always centred, but always being a focus (Kress and Leeuwen, 2006). In the Indonesian version advertisement, a background song which accompanied the linguistic element was contained. Actually, the linguistic element is a song which was made so the advertisement became attractive and also becoming a unique symbol of the Indomie advertisement. But there is nothing in this audio element that influenced the meaning can be found.

\section{Conclusion}

In this advertisement, the element of kebhinekaan was reflected in every aspect. Through the verbal from dari Sabang sampai Merauke, the description of togetherness of the people, also the display of the advertisement background which showed how rich the nature of Indonesia is. The whole of the advertisement contained five semiotic elements which formed the message of the advertisement multimodal text.

\section{References}

[1] Kasali, R. 2007. Manajemen Periklanan, Konsep Dan Aplikasinya Di Indonesia. Jakarta: Pustaka Utama Grafiti.

[2] Sinar, T. S. 2012. Teori \& Analisis Wacana Pendekatan Linguistik Sistemik Fungsional. Medan: Mitra

[3] Nurmala. 2011. Pengaruh Iklan Televisi Terhadap Minat Beli Sabun Mandi. Jurnal Aplikasi Manajemen. Vol. 9. No. 1. 2011

[4] Rosa, N. R. 2014. Analisis Multimodal Pada Iklan Sunsilk Nutrien Sampo Ginseng. Jurnal: Kajian Linguistik. Program Studi Linguistik FIB USU, ISSN 1693-4660 Tahun ke 12, No. 2 Hal. (136-148). Terbit pada: Agustus2014.

[5] Anstey, M dan Bull, G. 2010. Helping Teacher To Explore Multimodal Texts: An electronicjournal for leaders in Education.

[6] Sugiyono. 2005. Metode Penelitian Administrasi. Bandung: alfabeta

[7] Moleong, J. 2011. Metode Penelitian Kualitatif. Bandung: PT Rosdakarya.

[8] Arikunto, S. 2006. Prosedur Penelitian Suatu Pendekatan Praktik, Ed Revisi VI. Jakarta: PT Rineka Cipta.

[9] Munday, J. (ed.). 2009.The Routledge Companion To Translation Studies (Revised Edition) London and New York: Routledge.

[10] ..... 2008. Metode Penelitian Kunatitatif Kualitatif dan R \& D. Bandung: Alfabeta.

[11] Bungin, B. H. M. 2007.Penelitian Kualitatif: Komunikasi, Ekonomi, Kebijakan Publik, dan Ilmu Social. Jakarta: Kencana Prenama Media Group

[12] Halliday, M. A. K. 2004.An Intoduction To Functional Grammar. New York: Oxford University Press Inc.

[13] Miles, M. B, Huberman, A. M. dan Saldana, J. 2014. Qualitative Data Analysis [A Methods Sourcebook]. London: Sage Publications. 